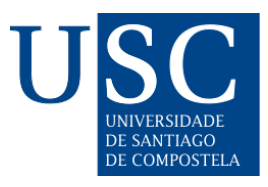

\title{
Rethinking the Politics of Israel/Palestine. Partition and its Alternatives
}

\author{
Rafael Arjona Soria \\ Student of Peace, Security and International Conflict MA, University of Santiago de Compostels, España \\ rafael.arjona@rai.usc.es
}

Oneself could believe, when talking about the question of Palestine, that this is a lingering, intractable and endless conflict that has not any possible solution, what makes vain any effort to achieve a peaceful settlement of the dispute. Notwithstanding, Rethinking the Politics of Israel/Palestine, Partitions and its Alternatives ${ }^{1}$ is a compound of essays from different scholars, intellectuals and politicians from the context of Israel-Palestine with the aim to open a new grammar for the conflict far from the traditional nation-state and partition approach. This volume, edited by Professor Bashir Bashir ${ }^{2}$ and Azar Dakwar ${ }^{3}$ was published by the Group of the Progressive Alliances of Socialist and Democrat in the European Parliament and by the Bruno Kreisky Forum, as a result of the project Alternatives to Partition, promoted by the latter and which sought, by thinking out of the box, to explore alternatives to the conflict that can overcome the everlasting paradigm of partition in Israel-Palestine.

The logic of partition has been the stem from where all the debates - and peace conversations - since the United Nations Resolution 181 until the Camp David Conversations or the Oslo Accords- have been based on, assuming that the claims of Jewish Zionist and Arab Palestinians are incompatible. Therefore, for partition advocates, there is no other scenario by which the conflict will be solved rather than the physical separation of both communities, what inevitable, leads to the creation of two ethno-national states where citizenship is defined by ethnicity and not by the mere individuality. As such, the aim of this volume is not to confront wholly the partition theory, since it could work in other contexts if certain conditions are met -such as if trust between two sovereign and democratic states exists, as Gianni Pittella comments in the Foreword, but to demonstrate the failure of the Two State Solution since the conditions for partition are no longer existing from the river to sea -as it is also named the territory of the extinct British Mandate in Palestine. Consequently, it is high time to consider alternatives to the traditional methods of conflict resolution that had been applied to the territory of Israel-Palestine, being urgent the need for a new paradigm which change the scope from partition and segregation to a shared sovereignty and ethnic-cooperation one.

Hence, what it is proposed in this volume is the theory of Binationalism. It is presented here as the new paradigm that understand the complex and intertwined reality of Israel-Palestine, changing the scope from the institutional designs that had proved its inefficiency to a set of principles focused on equal rights, both individually and collectively, of both peoples. This theory emerged from the 
failure of the Two State Solution, which has on the peace process that started with the Oslo Accords its last attempt to solve the conflict. For the scholar Raed Zreik, in "Two States as Apology" the Two States Solution is more the perpetuation of the current reality ad infinitum, whatsoever, it is seen more as a tool to manage the conflict rather than to transform and to solve it inasmuch as it hides the present reality by creating two symmetrical entities: the Palestinian Authority and the State of Israel, when there is clearly only one single, real, and sovereign entity on the ground: Israel. Thus, Binationalism recognises that it is a fact on the ground that there are two peoples, but only one State, what creates an asymmetrical context, where Israel acts as an occupying force and where Palestinians are stateless people who still have pending the recognition of the right of selfdetermination.

In addition to this manifest asymmetry, an examination of the reality of both peoples and the territory forces us to rethink partition in terms of viability. Bashir Bashir in Where Now for Israel / Palestine? Introduction \& Framing points that there are some striking realities that undermine partition such as the Israeli colonial settlements in the West Bank, the Arab -second class- citizens with Israeli citizenship, the dependence on the same water resources or the lack of territorial contiguity and demographic homogeneity. Accordingly, these realities reflect the core of the Binational theory, the fact that the territory of Israel-Palestine must be shared by its two peoples instead of being divided in that partition could yield exchange of populations, ethnic cleansing, despair and genocide, which is unacceptable and unmoral. In essence, the Binational theory acknowledges the fact that there are two peoples who have legitimate rights attached to the same territory and that those rights must be exercised on the basis of equality, non-exclusiveness and partnership due to the circumstances previously mentioned.

Likewise, the complexity of this conflict obligates both peoples to jointly -in the sense of respect each other or even partnership in some cases- exercise its rights. That means that a new start is needed from the river to sea -as Hannes Swoboda mention on After Weapons Spoke, Human Rights Must Prevail. This new start lies on the implementation of a right-based approach -as aforesaid before- to the conflict as opposed to institutional solutions which do not promote any formulas for cooperation between both peoples. As such, this rejection of mere institutional designs does not mean that the Binational advocates do not have its own constitutional proposals, for instance, a confederation or a federation of two states are the most popular alternatives among them, although what it must be highlighted is that previously to any discussion about institutions take place, both peoples must have guaranteed the equal and freely exercise of their fundamental rights, since the denial of the legitimate political rights that the Palestinians have been suffered even before the Nakba is the main cause of this conflict. That means that due to the actual asymmetrical situation between the occupied and the occupier -that shows high levels of interdependence and evidence the impossibility of separating both peoples- any peacebuilding initiative is forced to primarily assured the rights of both people before trying to implement any institutional design, which in my opinion, is what makes Binationalism a valuable and useful tool for Israel-and Palestine, whereas all the drawbacks that it could face, since it attends the main claims of Palestinians without excluding Jewish Zionist claims of the map and vice versa.

For that reason, Binationalism could be considered not only as a political framework which tries to implement certain institutional design but also as an innovative framework that goes beyond politics by focusing on both communities and its members instead of its political organization. Binationalism is presented here as a reasonable alternative that does not try to remedy an injustice -the Israeli Occupation- with another form of oppression just like Leila Farsakh in New Paradigm 
for Israel / Palestine points, furthermore, it does not impose any particular proposal, yet it seeks, as aforementioned, to introduce a set of principles that guarantee the individual and collective rights of both people. For the advocates of this theory, Binationalism is a feasible alternative for the context of Israel-Palestine such that it neither deny that a process of restorative justice and historical reconciliation must take place with all its consequences for both sides nor it aspires to an unattainable ideal, since its aim is not to force the two peoples to live in harmony as if nothing had happened but to assure a threshold of equality and parity between them.

Nonetheless, far from the theoretical point of view, the implementation of this theory raises a number of challenges not only for the people and politicians in the context of Israel-Palestine, but also to the international community. In the first place, this equal-rights premise need a strong political will and determination by both political unit's in order to abandon the traditional paradigm -which seems to be even harder whilst the European Union or the United Nations still believe and promote partition. How herculean would be the effort from the Jewish Zionist Political wing to start talking about dismantling privileges and the racist and discriminatory political system within Israel? Under what circumstances the State of Israel would be willing to lose it exclusive Jewish character in order to include Palestinian Arabs? Moreover, how Palestinians, which are clearly politically disunited and fragmented, will refuse the eternal but never performed promise of statehood? How to include the Arab minority that lives in Israel if partition finally take place? How the people from the West Bank will normalise the presence of the Jewish settlers, which indeed, are the most extremist people from the river to sea, politically and religiously speaking?

On the whole, these questions could be answered with one word: peace. Although that might sound simplistic, peace will bring opportunities and development for Palestinians and for Israelis, it would normalise its presence in the Middle East and the chance to abandon the systemic fear that characterised its public policy and to achieve that, a new paradigm far from the traditional nationstate logic must be embraced in the context of Israel-Palestine. The transformations that the conflict and the land had suffered along the whole history of the conflict evidence that the logic of partition is no longer relevant for the future of the conflict. As a matter of fact, acknowledging this thesis -the failure of the Two State Solution- and swiping to other alternatives is more about the necessity to find other means to achieve peace rather than a matter of opinion, as reality from the river to the sea shows us. On this basis, Binationalism is not presented here as the definite and ultimate settlement to the conflict, as there are other options, such as a One State Solution based on a secular democracy that also offer interesting aftermaths for the dispute. Nevertheless, the current state of affairs of the conflict presents a unique opportunity to abandon the traditional patterns and to change to a more updated and refreshed ones. Israelis, Palestinians and the International Community must be aware that the present status quo of the conflict is unattainable, being necessary to put an end this timeless conflict. 


\section{Información Adicional:}

Título: Rethinking the Politics of Israel/Palestine. Partition and its Alternatives

Autor: Bashir, B. y Dakwar, A.

Editorial: Bruno Kresky Forum and S\&D

Año de edición: 2014

Páginas: 145

ISBN: 978-3-950-0-5

NOTAS

1 The book can be found in the following address: https://issuu.com/brunokreiskyforum/docs/rethinking_- the politics_of israel

2 Bashir Bashir is a research fellow at the Van Leer Jerusalem Institute and teaches Political philosophy in the Department of Political Science at the Hebrew University of Jerusalem. His primary research interests are citizenship and nationalism studies, multiculturalism, and the politics of reconciliation.

3 Azar Dakwar is an independent research assistant, project developer and teaching associate with various organisations and universities. He also serves as the co-director of "Shared Public Space" project at Sikkuy the Association for the Advancement of Civic Equality. 